\title{
The COVID-19 pandemic lockdown causes a decrease in the number of cases of other infectious diseases in Poland
}

\author{
Ewa Czerwińska, Leszek Szenborn \\ Department of Pediatric Infectious Diseases, Wroclaw Medical University, Wroclaw, Poland
}

\section{ABSTRACT}

Introduction: Severe acute respiratory syndrome coronavirus 2 (SARS-CoV-2) is a causative agent of the ongoing pandemic. It can be transmitted among people via respiratory droplets generated while talking, coughing, or sneezing by an infected person. There is no known specific treatment or vaccine to prevent the coronavirus disease 2019 (COVID-19). The most effective way of limiting the spread of the virus is physical distancing combined with proper respiratory and hand hygiene. Many countries, including Poland, introduced restrictions in everyday life to control the pandemic. However, it has not been examined how these measures change the incidence of other infectious diseases.

Material and methods: Data from biweekly reports on infectious diseases and poisonings published by National Institute of Public Health - National Institute of Hygiene (Narodowy Instytut Zdrowia Publicznego Państwowy Zakład Higieny) were collected. The incidence of common and serious infectious diseases in the period 1.01.2020 to 15.05.2020 was evaluated and compared to the corresponding period from the year 2019. Results: A significant drop in the number of reported infectious diseases can be seen in the middle and at the end of March. These observations correlate with the time of introducing social distancing in Poland. The total number of reported cases, with the exception of pertussis, in the examined period is lower than in the year 2019.

Conclusions: The results indicate that keeping physical distance and proper hygiene undoubtedly reduce the transmission of various infectious agents among people. However, there a long-term study is needed to observe trends in incidence of selected infectious diseases. It can be assumed that before the pandemic Polish society was not aware of the importance of social distancing and did not make use of hygiene as a method of infectious disease prevention. Further education should be continued and intensified.

\section{KEY WORDS:}

COVID-19, transmission, prevention, infectious diseases.

\section{INTRODUCTION}

Coronavirus disease 2019 (COVID-19) is a contagious disease caused by severe acute respiratory syndrome coronavirus 2 (SARS-CoV-2). It was first reported in China as a severe pneumonia of unknown origin at the end of 2019. Within a few weeks the pathogen was identified as a novel coronavirus [1]. As the disease has been spreading globally, the World Health Organization declared the outbreak a pandemic on 11 March 2020 [2].

Infectious diseases can be transmitted in different modes. One of the classifications distinguishes direct (direct contact, droplet spread) and indirect (airborne, vehicle-borne, vector-borne) modes. [3] The knowledge about modes of transmission of infectious diseases is necessary to prevent them. Introducing various interventions

\section{ADDRESS FOR CORRESPONDENCE:}

Ewa Czerwińska, Department of Pediatric Infectious Diseases, Wroclaw Medical University, 2-2a Chałubińskiego St.,

50-368 Wroclaw, Poland, ORCID: 0000-0002-8236-1779, e-mail: czerwinska.ed@gmail.com 
that break the chain of infection contribute to the reduction of the number of infected patients. These measures can be specific, like immunisations, or non-specific. Intuitively, general preventive measures include separation and treatment of infected individuals, quarantine of people that have a high risk of having been infected, social distancing, hand hygiene (frequent handwashing with soap and water, rubbing hands with an alcohol-based solution), respiratory hygiene (covering mouth and nose while sneezing or coughing, using disposable tissues, throwing away used tissues), avoiding touching the mouth, nose, and eyes before handwashing, ensuring frequent room ventilation, avoiding animal bites, limiting exposure to contaminated sand, soil, and water, proper food preparation, cleaning, sanitising, and disinfecting surfaces, and wearing personal protective equipment (PPE) (gloves, gowns, masks) [4,5]. During the ongoing pandemic it has been proven that keeping a physical distance of one metre or more, using N95 or similar face masks, and eye protection significantly decreases SARS-CoV-2 transmission in health-care and community settings [6]. It has also been determined that lockdown measures introduced in China contributed to a decrease in the growth rate and an increase in the doubling time of cases of COVID-19 [7]. Earlier studies show that handwashing, barrier measures, and suspicion diagnosis with isolation of likely cases are useful in reducing transmission of viral respiratory diseases [5]. Although isolation of infected patients is obvious, quarantining of probably ill individuals may be controversial as it can lead to economic, social and psychological consequences. It was established that quarantine can be profitable when isolation is ineffective, the disease can be spread by asymptomatic people and the asymptomatic period is neither very long nor very short [8]. Another questionable control measure in limiting the spread of infectious diseases is screening travellers on entry and exit points. This method has many limitations, and its impact on detecting affected individuals is difficult to assess. However, it can have indirect positive outcomes, such as educating travellers or discouraging migration of ill people [9].

The aim of this study was to evaluate if the general lockdown, introduced by the Polish government, had any impact on the prevalence of common and serious infectious diseases.

\section{MATERIAL AND METHODS}

The data were collected from biweekly reports on cases of infectious diseases and poisonings in Poland published by National Institute of Public Health - National Institute of Hygiene (Narodowy Instytut Zdrowia Publicznego - Państwowy Zakład Higieny, NIZP - PZH) [10]. The number of patients suffering from infectious diseases was examined and compared before and after the introduction of social restrictions. The results were compared with corresponding data from the year 2019. The examined diseases include the following: viral gastrointestinal infections, indefinite diarrhoea and gastroenteritis, hepatitis A, invasive meningococcal disease, invasive Streptococcus pyogenes disease, invasive pneumococcal disease, Lyme disease, contact and exposure to rabies, pertussis, scarlet fever, rubella, mumps, chickenpox, and influenza.

These diseases are characterised by different modes of transmission, incubation periods, communicability periods, and possibilities of asymptomatic carriage ( $\mathrm{Ta}-$ ble 1). The selected diseases include common and serious infections, important in the everyday practice of paediatricians.

The data are incomplete because State Sanitary Inspection (Powiatowa Stacja Sanitarno-Epidemiologiczna - PSSE), Wroclaw reported only SARS-CoV-2 infections during the period 16.04.2020 - 15.05.2020 [10].

\section{RESULTS}

The general lockdown caused a decrease in the spread of the majority of other infections. There are only slight differences in the number of cases of invasive meningococcal disease, which can be fortuitous. The number of reported infectious diseases declines in the middle or at the end of March, which corresponds to the dates of introduced restrictions and incubation periods of different diseases. The general number of infected patients is lower than during a comparable period in the year 2019, with the exception of pertussis.

The number of weeks in the tables and figures corresponds to the following calendar weeks.

There was a $63 \%, 69 \%$, and $67 \%$ drop in the average number of new cases of viral gastrointestinal infections, diarrhoea and gastroenteritis, and hepatitis A, respectively, during weeks 11-18 compared to weeks $1-10$ of the year 2020 (Fig. 1).

There was a $53 \%, 45 \%$, and $61 \%$ drop in the average number of new cases of invasive meningococcal disease, invasive S. pyogenes disease, and invasive pneumococcal disease, respectively, during weeks 11-18 compared to weeks 1-10 of the year 2020 (Fig. 2).

There was an $81 \%, 82 \%, 79 \%, 74 \%$, and $72 \%$ drop in the average number of new cases of pertussis, scarlet fever, rubella, mumps, and chickenpox, respectively, during weeks 11-18 compared to weeks 1-10 of the year 2020 (Fig. 3).

A similar tendency can be observed regarding influenza. There was a decrease in the number of reported cases in all Polish voivodeships [11]. The decline can be observed at the beginning and in the middle of March (week 9-10) because influenza has short incubation period (Table 1). 


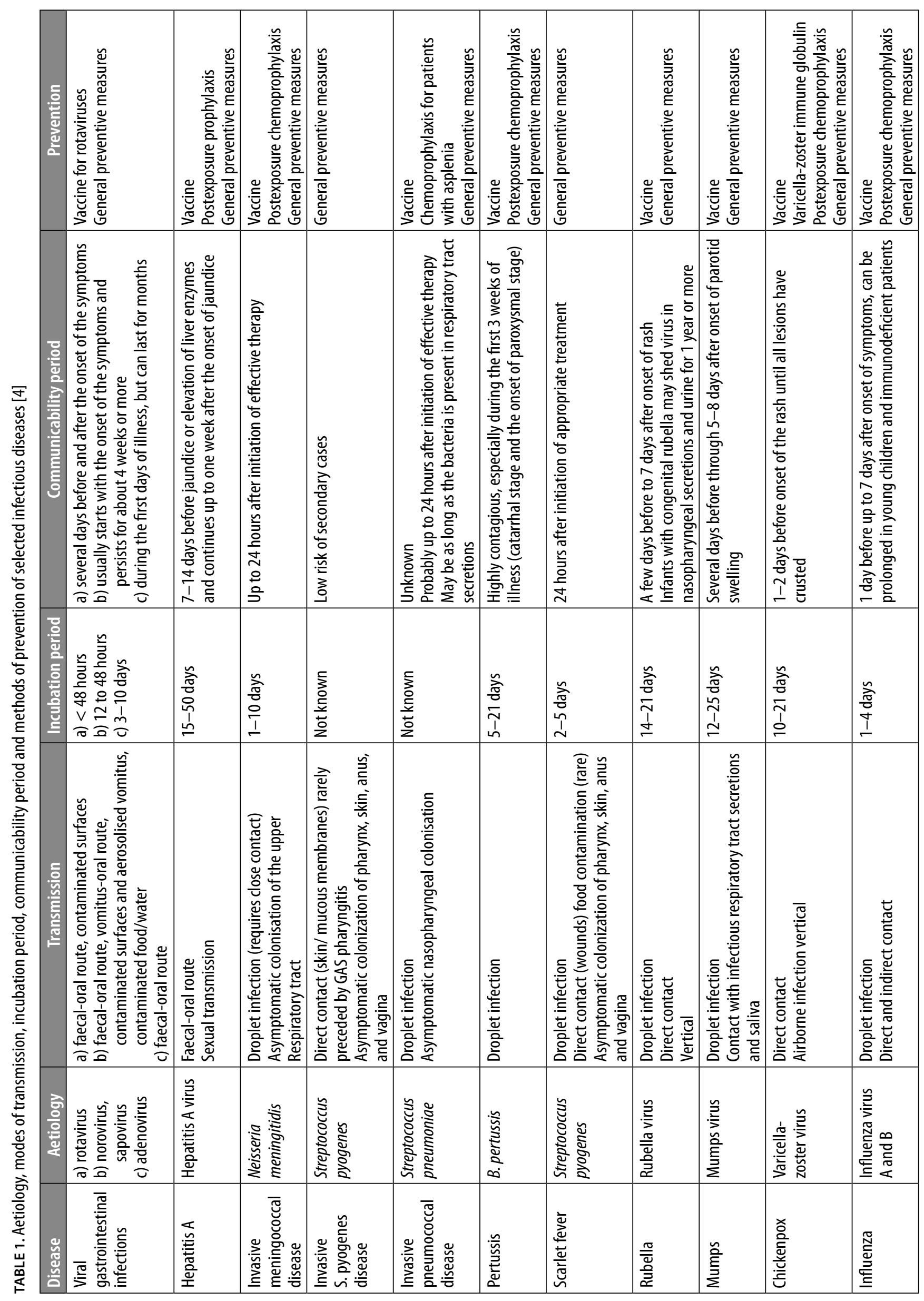



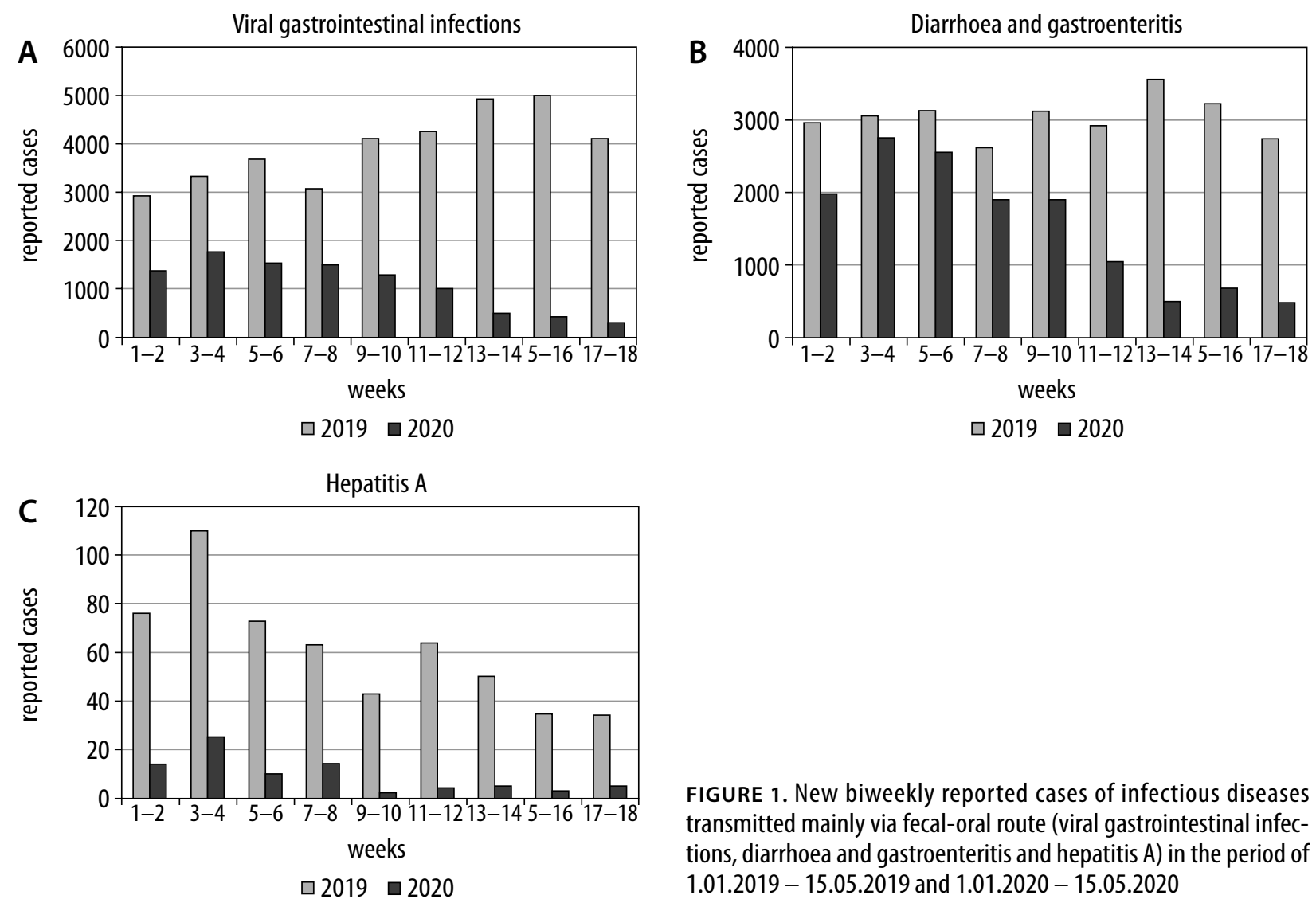

FIGURE 1. New biweekly reported cases of infectious diseases transmitted mainly via fecal-oral route (viral gastrointestinal infections, diarrhoea and gastroenteritis and hepatitis $A$ ) in the period of 1.01.2019 - 15.05.2019 and 1.01.2020 - 15.05.2020
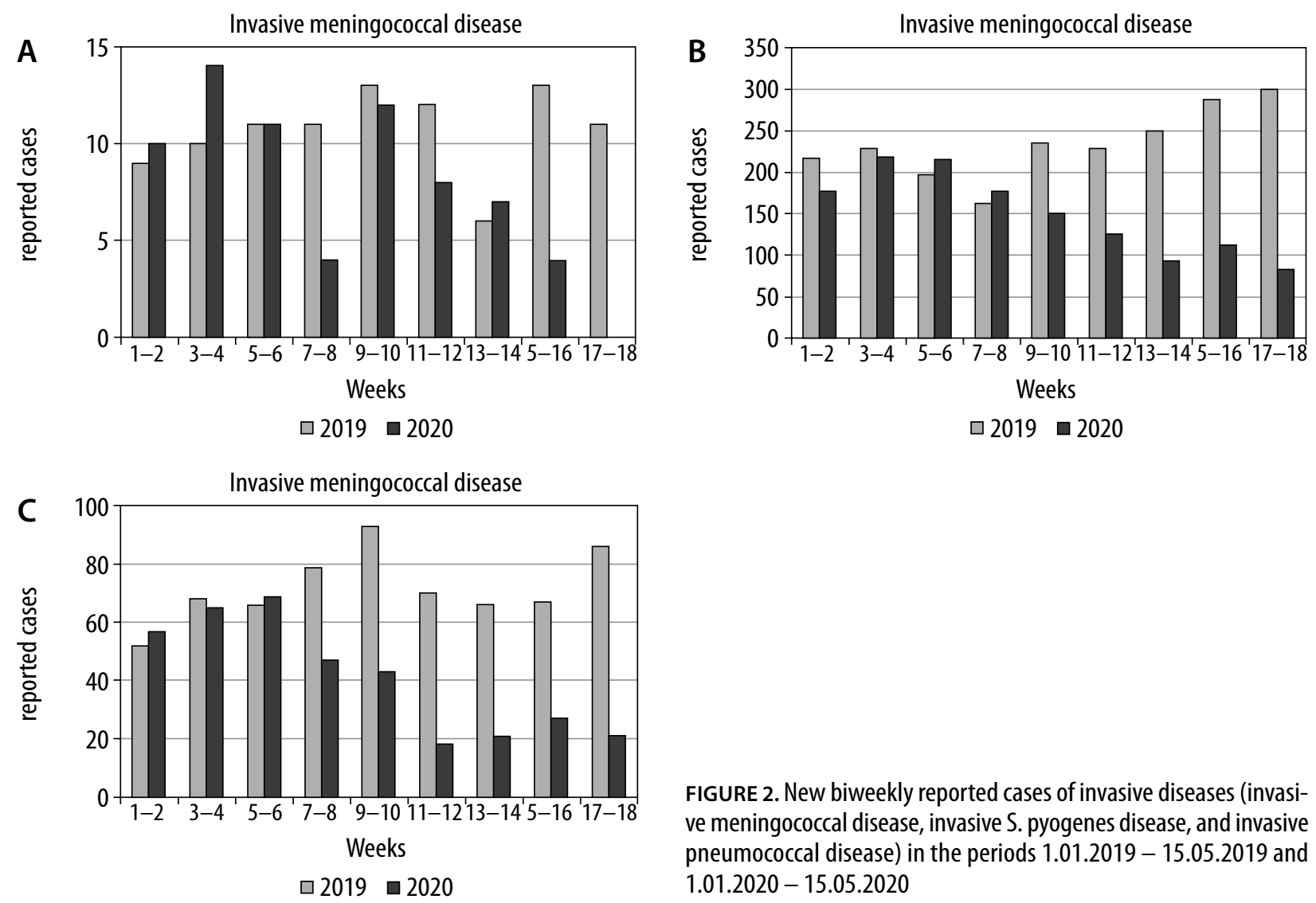

FIGURE 2. New biweekly reported cases of invasive diseases (invasive meningococcal disease, invasive S. pyogenes disease, and invasive pneumococcal disease) in the periods 1.01.2019-15.05.2019 and 1.01.2020 - 15.05.2020 

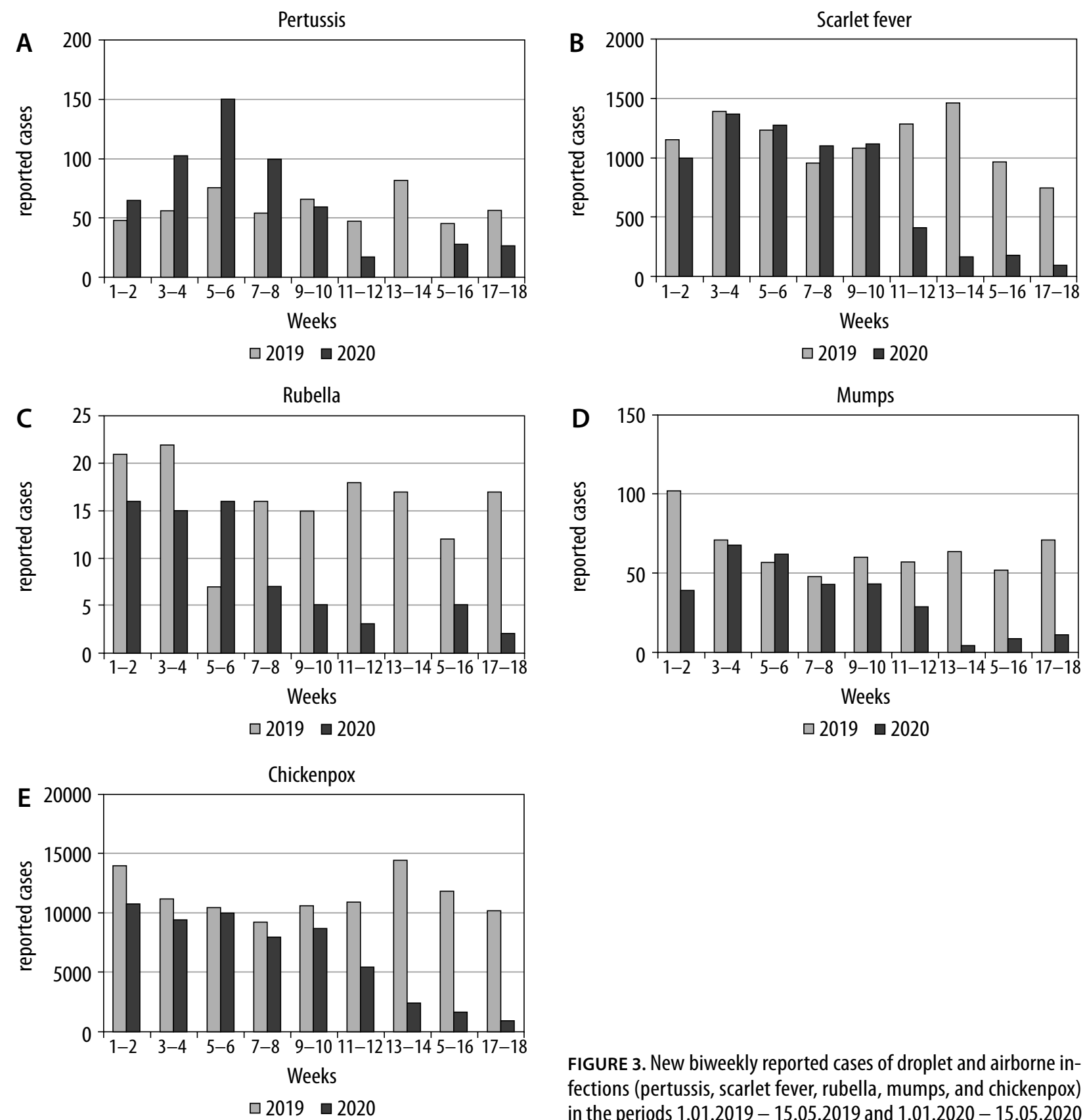

FIGURE 3. New biweekly reported cases of droplet and airborne infections (pertussis, scarlet fever, rubella, mumps, and chickenpox) in the periods 1.01.2019-15.05.2019 and 1.01.2020 - 15.05.2020

There was a $73 \%$ drop in the average number of new cases of influenza during weeks 11-18 compared to weeks $1-10$ of the year 2020 (Fig. 4).

A decreasing trend in the number of new cases of animal-transmitted diseases can also be noticed. The general lockdown contributed to a reduction of reported cases of Lyme disease and exposure to rabies.

There was a $70 \%$ and $41 \%$ drop in the average number of new cases of Lyme disease and exposure to rabies, respectively, during weeks 11-18 compared to weeks 1-10 of the year 2020 (Fig. 5).

\section{DISCUSSION}

On 4 March there was the first reported, laboratoryconfirmed SARS-CoV-2 infection in Poland [12]. With-

in days the number of confirmed cases increased, and on 10 March Poland was qualified as a country with local transmission [13]. In connection with the spread of SARS-CoV-2, on 14 March the Polish government introduced a state of epidemic emergency [14] and on $20 \mathrm{March}$, a state of epidemic [15]. To slow down the coronavirus circulation and avoid overloading hospitals, many restrictions were announced, including a temporary general lockdown for all citizens, with some exceptions. Nurseries, kindergartens, schools, and universities were closed. Work from home was recommended whenever possible. Any mass gatherings, including cultural events were cancelled, and limitations in the number of people taking part in religious events were introduced. Starting from 16 April it was obligatory to cover one's nose and mouth in public places [16]. It was reiterated $[17,18]$ that 


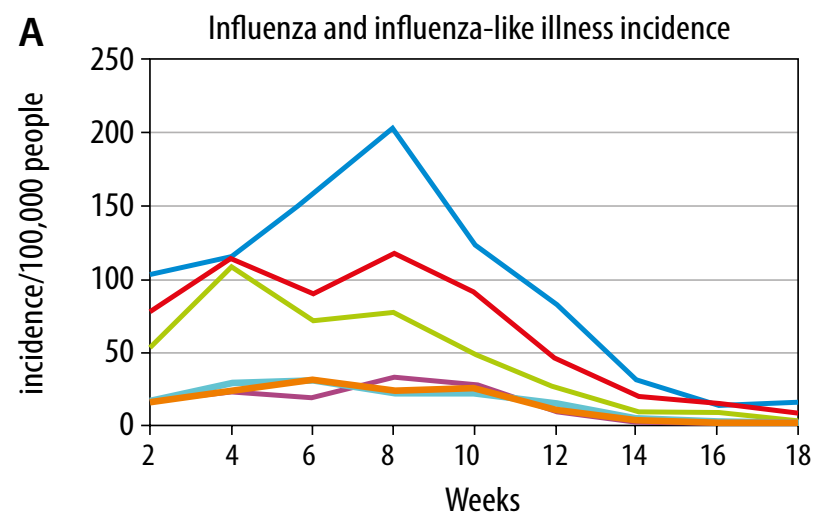

— Pomorskie
— Wielkopolskie
- Malopolskie
— Lubuskie
- Opolskie
- Zachodniopomorskie

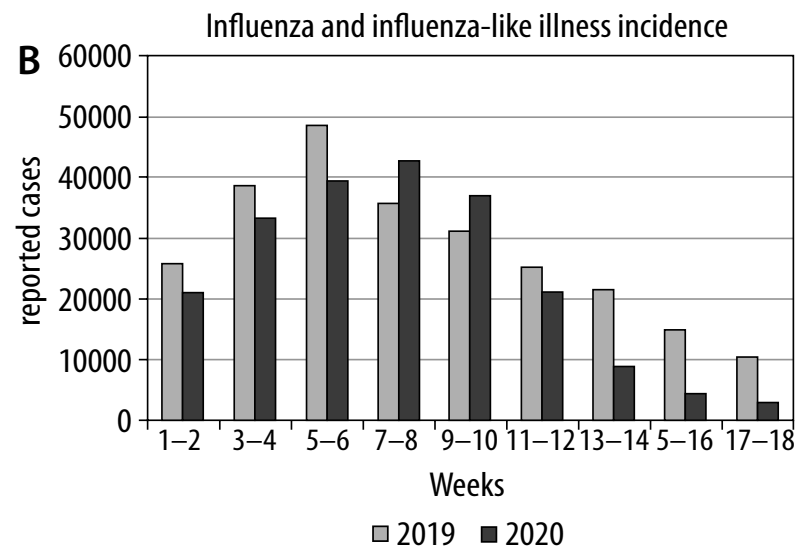

FIGURE 4. The influenza and influenza-like illness incidence per 100,000 people in selected Polish voivodeships with the highest and the lowest incidence rate in the period 1.01.2019-15.05.2019 and new biweekly reported cases of influenza and influenza-like illness in the periods 1.01.2019-15.05.2019 and 1.01.2020 - 15.05.2020

proper and frequent hand hygiene is known to prevent the spread of many infectious diseases [19-22]. All these interventions were administered as a possible method of reducing the transmission of SARS-CoV-2.

According to our knowledge, there is no study concerning changes in the incidence of different infectious diseases during the COVID-19 pandemic. The results of this research confirm the efficacy of the isolation measures introduced because of the ongoing pandemic on transmission of other infectious diseases. A very high percentage reduction in the number of different communicable diseases can be observed. However, the number of newly reported cases of droplet and airborne diseases did not decrease or dropped only slightly after introduction of the obligation of covering one's nose and mouth in public places, which may suggest that social distancing alone is more effective. It is hard to estimate the impact of compulsory face covering on the incidence of influenza
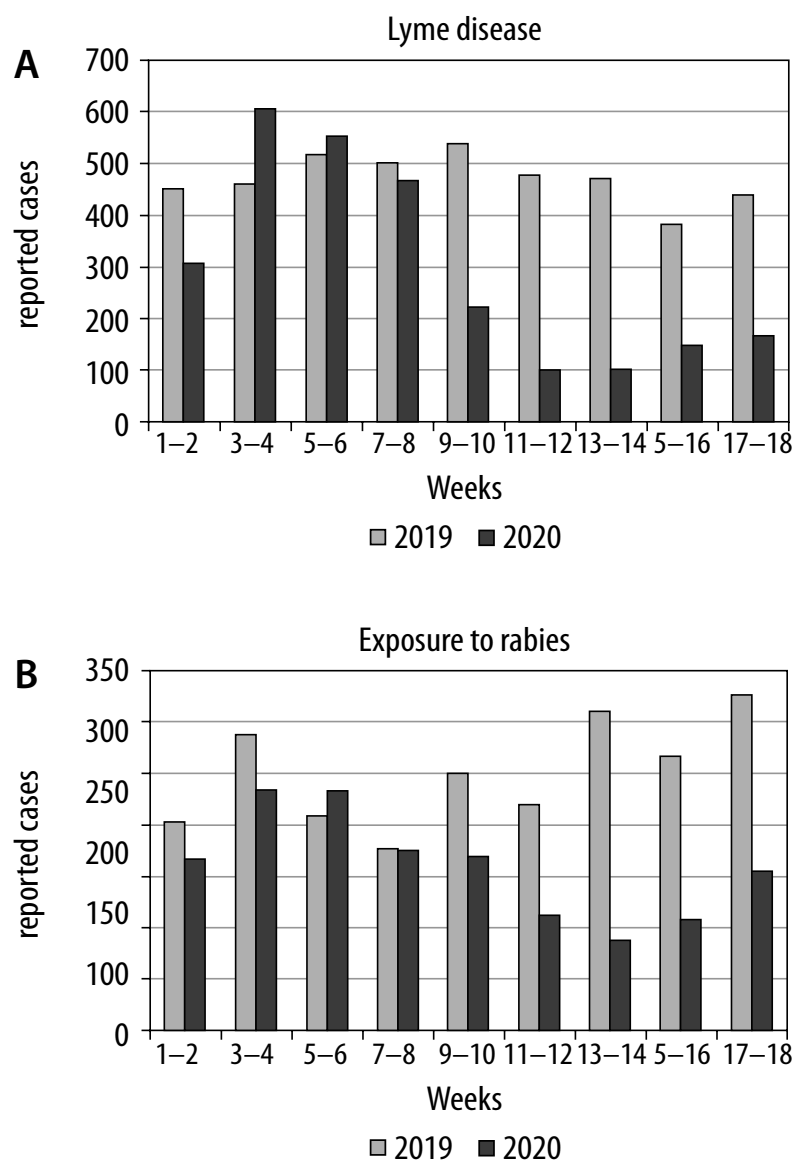

FIGURE 5. New biweekly reported cases of animal transmitted diseases (Lyme disease and exposure to rabies) in the periods 1.01.2019 -15.05 .2019 and $1.01 .2020-15.05 .2020$.

because this time of the year corresponds with the end of influenza season.

A decrease in the number of reported animal bites resulting in the need for rabies prophylaxis, as well as new cases of Lyme disease, once more underlines the strong effect of the general lockdown on reducing the transmission of infectious diseases. It can be assumed that limited access to doctor's visits and private laboratory analyses resulted in a reduction in overdiagnosis of Lyme disease.

The results may be underestimated because many healthcare institutions organise mainly online consultations, so patients are not thoroughly examined and some diseases can be overlooked. However, a decrease observed in the number of invasive diseases, which always require examination and specific treatment, may suggest that the morbidity of other, less severe infectious diseases is lower as well.

\section{CONCLUSIONS}

To summarise, it can be assumed that Polish society took the above-mentioned social restrictions seriously. Social distancing, respiratory hygiene, and frequent hand washing contributed to a decline in reported cases of other infectious diseases. Public awareness on infectious 
diseases transmission and prevention plays an important role in stopping the spread of these diseases. Further intensive education on this topic is needed among Poles.

\section{DISCLOSURE}

The authors declare no conflict of interest.

\section{REFERENCES}

1. Lai CC, Shih TP, Ko WC, et al. Severe acute respiratory syndrome coronavirus 2 (SARS-CoV-2) and coronavirus disease-2019 (COVID-19): The epidemic and the challenges. Int J Antimicrob Agents 2020; 55: 105924

2. World Health Organization. WHO Director-General's opening remarks at the media briefing on COVID19 - March 2020 [Internet]. Available from: https://www.who.int/dg/speeches/detail/who-director-general-s-opening-remarks-at-the-media-briefing-on-covid-19--11-march-2020 (access: 13 May 2020).

3. Centers for Disease Control and Prevention. Principles of Epidemiology [Internet]. Available from: https://www.cdc.gov/csels/dsepd/ ss1978/lesson1/section10.html (access: 25 May 2020).

4. Kimberlin D, Brady M, Jackson M, Long S. Red Book: 2018-2021 Report of the Committee on Infectious Diseases. 31st ed. American Academy of Pediatrics 2018.

5. Jefferson T, Del Mar CB, Dooley L, et al. Physical interventions to interrupt or reduce the spread of respiratory viruses. Cochrane $\mathrm{Da}$ tabase Syst Rev 2011; 2011: CD0062072011.

6. Chu DK, Akl EA, Duda S, et al. Physical distancing, face masks, and eye protection to prevent person-to-person transmission of SARSCoV-2 and COVID-19: a systematic review and meta-analysis. Lancet 2020; 395: 1973-1987.

7. Lau H, Khosrawipour V, Kocbach P, et al. The positive impact of lockdown in Wuhan on containing the COVID-19 outbreak in China. J Travel Med 2020; 27: taaa037.

8. Day T, Park A, Madras N, et al. When is quarantine a useful control strategy for emerging infectious diseases? Am J Epidemiol 2006; 163: 479-485.

9. Mouchtouri VA, Christoforidou EP, der Heiden MA, et al. Exit and entry screening practices for infectious diseases among travelers at points of entry: Looking for evidence on public health impact. Int J Environ Res Public Health 2019; 16: 4638.

10. Zakład Epidemiologii Chorób Zakaźnych i Nadzoru NIZP-PZH. Informacje o zachorowaniach na choroby zakaźne i zatruciach w Polsce w 2020 roku [Internet]. Available from: http://wwwold. pzh.gov.pl/oldpage/epimeld/index_p.html (access: 22 May 2020).

11. Zakład Epidemiologii Chorób Zakaźnych i Nadzoru NIZP-PZH. Zachorowania i podejrzenia zachorowań na grypę w Polsce [Internet]. Available from: http://wwwold.pzh.gov.pl/oldpage/epimeld/ grypa/index.htm (access: 16 May 2020).

12. Ministerstwo Zdrowia. Pierwszy przypadek koronawirusa w Polsce [Internet]. Available from: https://www.gov.pl/web/zdrowie/ pierwszy-przypadek-koronawirusa-w-polsce (access: 13 May 2020).

13. World Health Organization. Coronavirus disease 2019 (COVID-19) Situation Report - 50. World Health Organization, 2020.

14. Rozporządzenie Ministra Zdrowia z dnia 13 marca 2020 r. w sprawie ogłoszenia na obszarze Rzeczypospolitej Polskiej stanu zagrożenia epidemicznego (Dz.U. z 2020 r. poz. 433).

15. Rozporządzenie Ministra Zdrowia z dnia 20 marca 2020 r. w sprawie ogłoszenia na obszarze Rzeczypospolitej Polskiej stanu epidemii (Dz.U. z 2020 r. poz. 491).
16. Rozporządzenie Rady Ministrów z dnia 15 kwietnia 2020 r. zmieniające rozporządzenie w sprawie ustanowienia określonych ograniczeń, nakazów i zakazów w związku z wystąpieniem stanu epidemii (Dz.U z 2020 r poz. 673).

17. Główny Inspektorat Sanitarny. Informacja Głównego Inspektora Sanitarnego w związku z potencjalnym ryzykiem zakażenia koronawirusem [Internet]. Available from: https://gis.gov.pl/aktualnosci/ informacja-glownego-inspektora-sanitarnego-w-zwiazku-z-potencjalnym-ryzykiem-zakazenia-koronawirusem/ (access: 22 May 2020).

18. Główny Inspektorat Sanitarny. Dekalog bezpiecznego zachowania podczas epidemii koronawirusa [Internet]. Available from: https:// gis.gov.pl/bez-kategorii/dekalog-bezpiecznego-zachowania-podczas-epidemii-koronawirusa/ (access: 22 May 2020).

19. Centers for Disease Control and Prevention. Show Me the Science Why Wash Your Hands [Internet]. Available from: https://www.cdc. gov/handwashing/why-handwashing.html (access: 21 May 2020).

20. Luby SP, Agboatwalla M, Feikin DR, et al. Effect of handwashing on child health : a randomised controlled trial. Lancet 2005; 366 : 225-233.

21. Rabie T, Curtis V. Handwashing and risk of respiratory infections : a quantitative systematic review. Trop Med Int Heal 2006; 11: 258-267.

22. Curtis V, Cairncross S, Yonli R. Review: Domestic hygiene and diarrhoea - pinpointing the problem. Trop Med Int Heal 2000; 5: 22-32. 